\title{
Annual displacements, strain partitioning and pore pressure variation in the Triesenberg Earthflow
}

\section{Other Conference Item}

Author(s):

Maissen, Jasmin; Loew, Simon (ID; Aaron, Jordan

Publication date:

2021

Permanent link:

https://doi.org/10.3929/ethz-b-000510378

Rights / license:

Creative Commons Attribution 4.0 International

Originally published in:

EGUsphere, https://doi.org/10.5194/egusphere-egu21-8463 


\title{
EGU21-8463
}

https://doi.org/10.5194/egusphere-egu21-8463

EGU General Assembly 2021

(c) Author(s) 2021. This work is distributed under

the Creative Commons Attribution 4.0 License.

\section{Annual displacements, strain partitioning and pore pressure variation in the Triesenberg Earthflow}

\author{
Jasmin Maissen, Simon Löw, and Jordan Aaron \\ Geological Institute, ETH Zurich, Zurich, Switzerland (jasmin.maissen@erdw.ethz.ch)
}

Large landslide complexes in flysch are among the largest landslides on earth. These landslides often feature a rotational landslide at the head, the weathering and downslope transport of which produces one or more earthflows that terminate in a bulging toe at a valley bottom. These landslide complexes typically undergo ductile movements, on the order of mm/year to $\mathrm{cm} /$ year, and thus loss of life risk is typically low. However, the earthflow portions of these complexes can surge, which can result in significant infrastructure damage. Thus, understanding annual landslide displacements, the partitioning of strain within the landslide body, as well as subsurface groundwater recharge are crucial factors for understanding and managing these landslide complexes.

In the present work we present and analyze a uniquely detailed dataset collected for the Triesenberg Landslide, a landslide complex in Flysch located in Liechtenstein. This dataset contains accurate measurements of surface displacements that occurred between 1978 and 2012, InSAR displacement time series from 2011 to 2020, periodic measurements (once or twice a year) of over 30 inclinometers since 1995, continuous and periodic pore pressure measurements at a number of locations since 2001 as well as climatic data from nearby climate stations. We combine the surface and subsurface displacement measurements to understand how strain is partitioned in the landslide, as well as seasonal and annual landslide displacement rates. We then combine porepressure measurements and climatic data to investigate groundwater recharge mechanisms, as well as the water balance of our study area. The analysis of the InSAR data, as well as its comparison to previous displacement measurements, reveals annual displacement rates up to 4.5 $\mathrm{cm} / y e a r$. Additionally, the inclinometer data shows that the depth to the rupture surface varies throughout the landslide body, and is measured as deep as $70 \mathrm{~m}$ in some locations. Surprisingly, very few internal shear planes were noted within the earthflow portion of the landslide. We find that recharge into the landslide body is complex, and that the water mass balance is potentially influenced by the adjacent Valuna valley. By combining these analyses, we are able to gain preliminary insights into the behavior of the Triesenberg landslide, which has important implications for understanding this landslide as well as many other landslide complexes in flysch. 